\title{
Implementation of Mind Mapping Learning Methods in Efforts to Improve the Research and Examination of Seminars on the College of Public Policy Seminar as FISIPUMSU Products
}

\author{
${ }^{1}$ Dedi Amrizal, ${ }^{2}$ Yusriati \\ ${ }^{1}$ Social Science and Politics Faculty, University of Muhammadiyah Sumatera Utara (UMSU) Medan, Indonesia \\ ${ }^{2}$ FKIP Faculty, University of Muhammadiyah Sumatera Utara (UMSU) Medan, Indonesia \\ Email: dediamrizal@umsu.ac.id
}

\begin{abstract}
Teaching Grant using mind mapping method is expected to be a reference in improving the learning system in public policy seminar courses in the Faculty of Political Science (FISIP), especially the State Administration Study Program (IAN). The low condition of mastery of the problem and the lack of ability to explain problems at the time of the seminar practice in this public policy seminar course made researchers interested in offering new learning methods with the name mind mapping that prioritizes images and signs for mapping research problems as well as can be used to help The student explained the research problem more clearly during the thesis proposal seminar.This study aims to assist students in finding research problems properly, improving students' ability in formulating problems and explaining problems in public policy seminars and ultimately expected to improve the quality of seminars and the quality of student answers in public policy seminars. The results showed that in the first cycle there was no significant development of the students involved so it was necessary to do a second cycle with the addition and improvement when training and making mind mapping and presentation. Finally in the second cycle, it can be seen that there are changes and improvements in the making of mind mapping and it can be seen that students find it easier to explain the research problem compared to mind mapping learning methods that can increase students' mastery of research problems and can facilitate them in explaining the problems at the seminar. Although the final achievement of the first cycle still shows confusion and low mastery of the mind mapping theory, in the second cycle there is a change in the mastery of theory and mind mapping (students realize that mind mapping cannot be done if they do not master the research problem correctly) so when explaining the problem of research in front of the class when the seminar practice takes place can be done better.In general, the use of mind mapping in public policy seminar courses is very useful and helps students in formulating research problems, making a research background, presenting a research background in the form of a power point containing mind mapping. And the most important thing is that mind mapping helps students in explaining the research problem at the time the seminar was held.
\end{abstract}

Keyword: mind mapping; learning methods; seminars 


\section{Introduction}

The success of students in presenting research problems well in front of lecturers and respondent students is an important skill in seminar courses. Mastery of science, research methods and the delivery of messages in public is a package that is inseparable in this public policy seminar course.The seminar is etymologically derived from the word seminary. David Lindsay (1986: 67) said that the seminar was an international meeting to discuss the results of research officially and unofficially. So a seminar is basically discussing research plans and research results. Presenting the results of the initial research at a proposal seminar and the presentation of the results of the research at the results seminar were not easy. Both require clear problems and straightforward explanations in a line of thought that others can understand.One problem that often occurs in State Administration Students (IAN) when attending public policy research methods and its advanced courses such as public policy seminars is when they try to get to know the problem, formulate the problem and explain the problem. This problem arises because of student weaknesses in two things: 1) lack of understanding of the concepts and theories related to basic knowledge they have; and 2) lack of knowledge of the types of methods they can use for state administration research. When viewed from the ability to find problems, formulate problems and explain the problems that exist to listeners in the seminar, it is seen the same repetition of the shortcomings (basic problems) of this Public Policy Seminar course in its implementation every year. The concepts and theories that have been given in the first and second year of the lectures they follow must be taught to be returned and dug up from the minds of students through a special technique or method and at the same time able to make students capable of describing and mapping the conditions of the problem to people others so that other people understand the location of the problem.

When a student is unable to find a problem in the concept he will adopt as a variable in a research title, he will have difficulty formulating the research background in his research proposal. This will bring difficulties to determine the method and theory that will be used in supporting the proposal later.This is one of the challenges that must be faced by lecturers in the Public Policy Seminar course to enable students to explore problems, formulate problems and map them and explain them to others. During this time the teaching methods provided by the lecturers seem monotonous and underdeveloped considering there are no challenges from the quality of students faced from year to year. Like facing humans of the same quality every year and using the same materials and techniques the following year. Seminar lecturers only introduce what is a problem, the source of the problem, and how to make a good problem formulation for a state administration research and pay less attention to the ability of students to find problems, formulate problems, map problems and explain to others the problem in a seminar proposal .To overcome this, the mind mapping research method is very effective when used to bring up the hidden ideas that we have and make associations between them. Mind Mapping is also useful for organizing information that is owned. The form of the diagram, which is like a tree diagram and branching makes it easy to reference one information to another. This method will greatly assist 
students in finding problems, formulating, describing and explaining to others in a seminar subject.Public policy seminar courses have been carried out as a chain of four interconnected subjects that are interrelated, including: Indonesian and scientific works, social research methods, research methods (public policy/ development administration) and finally seminar courses (public policy/ development administration). The ability to introduce scientific writing and scientific methods is done in Indonesian and scientific works, then the ability of students to recognize research methods through basic research theories in social research methods. In the next semester students are introduced to the application of methods and practice of field research with research methods (public policy and development). Finally, students will be matured with the ability to find problems to maintain the research method and data collection method chosen through seminar courses (public policy/ development administration).The fundamental problem experienced by IAN students during thesis writing is in mastering the basic theory of administration and research methods. This should be given well in introductory administration courses and social research methods. However, the initial obstacles presented above are obstacles to learning in this seminar course.Indications of low understanding and mastery of students in the basic theory of science and research methods can be seen from the quality of the answers given during the mid-semester exams and the final semester exams in this course the previous year.The method of presenting thesis proposal assignments which is usually done with a short discussion if anyone asks for these three years is not able to raise the quality of understanding and quality of mastering the research problem and the presentation of the research problem to the seminar participants. The low reading interest of students is the next obstacle that exacerbates the expected understanding of students. There must be new efforts to make it easier for them to find problems from the basis of scientific and research methods that have been taught previously.It is necessary to add learning methods that are done by looking at the basic weaknesses that exist in students and teaching techniques from the lecturers of this public policy seminar course. The weakness of students from the mastery of lecture material and the ability to explain again can be improved through the mind mapping method that is applied to this course. Through this method it is expected that the proposed problems can be mastered and formulated and easily explained by students.

\section{Theoretical Frame Work}

Sugandi (2004: 11) suggests that in a narrow sense, the learning process is an educational process within the scope of schooling so that the meaning of the learning process is the process of individual socialization of students with the school environment. According to the concept of communication, learning is a process of functional communication between students and teachers and students with students, in order to change students and the mindset that will become the habits of the students concerned.Djaafar (2001: 2) says that learning is an attempt to manage the environment intentionally so that someone learns to behave in certain conditions. According to Sugihartono (2007: 81), learning is an effort made by the teacher to deliver knowledge, organize, and create an environmental system with various methods so that students can do learning activities effectively and efficiently and with optimal results.From some opinions about learning 
above, it can be concluded that learning is the process of teaching and learning interaction involving learning components which include: learning objectives, learning materials, methods, teaching techniques, students, media, teachers and evaluation of learning outcomes. Emphasis on learning social research methods is not only to train skills in knowing concepts and types of methods but also to memorize and also to understand the concepts and methods properly.

\subsection{Definition of Method}

According to Sanjaya (2006: 147), the method is the method used to implement plans that have been compiled in real activities so that the goals that have been prepared are optimally achieved.According to Ghafur (1989: 46), the method is a way that helps to realize the process of activities that are maximal, effective and efficient. In role learning methods are very important, namely as a sub-system that contributes to creating active, creative learning and attracts students' attractiveness in learning seriously. So the "method" better describes the technique or steps. So we can say that the method is the method used to implement plans that have been arranged in real activities with a maximum, effective and efficient so that the objectives that have been set up are optimally achieved.Some meanings of the learning method according to Purwoto (1997: 70) include: a) The learning method is a way of teaching certain topics so that the process of the teaching works well; b) The learning method is the right and harmonious way in the best way possible, so that the teacher is successful in teaching him, so that teaching reaches the goal or about the goal; c) Learning methods are common teaching methods that can be applied or used for all fields of study.According to Wena (2011: 2), learning strategies or methods mean ways or art to use all learning resources in student learning efforts.According to Thaha (2004: 122), learning methods can also be said to be a lubricant for learning to achieve goals, because basically the learning method is a method used to facilitate the implementation of goal-oriented learning activities.According to Sudjana (2000: 76), the learning method is the method used by the teacher in making relationships with students during teaching. Meanwhile Tardif in Shah (1995: 202) said that the learning method is a method that contains standard procedures for carrying out educational activities, especially the activity of presenting the subject matter to students.According to Uno (2007: 65) the method of learning is the ways of the instructor or instructor to present new information or experience, explore the experiences of the participants, display the performance of the learning participants and others,Based on the description above, it can be concluded that the learning method is the method used by the lecturer to present the material and foster interaction in the learning process with the aim that students are motivated in learning and can increase their activities and creativity so as to achieve the expected competence, both in terms of cognitive, affective, and psychomotor.

\subsection{Mind Mapping Method}

Mind mapping is a way to put information into the brain and take it back out of the brain. Mind mapping is like a map of a road in a city that has branches. As befits a road map we can make a comprehensive view of the subject matter in a very wide area. By using a map, of course we can plan the fastest and right route and find out where we are going and where we are.Buzan (2008: 4) says that mind mapping is a way of developing thinking activities in all directions, 
capturing various thoughts in various angles. Mind mapping develops divergent thinking and creative thinking. Mind mapping that we often call concept maps is a great tool of organizational thinking which is also the easiest way to put information into the brain and retrieve that information when neededMind mapping can be called a route map that is used by memory, allowing us to compile facts and thoughts in such a way that the workings of our natural brain will be involved from the beginning so that remembering information will be easier and more reliable than using ordinary note-taking techniques. So, mind mapping, called mind mapping or mind maps, is one way to record subject matter that makes it easy for students to learn. Mind mapping can also be categorized as a creative note-taking techniqueCategorizing into creative techniques because making mind mapping requires the use of the imagination of the maker.

Creative students will more easily make this mind mapping. Likewise, with more and more students making mind mapping, they will be more creative in learning. The concept of mind mapping was originally introduced by Tony Buzan in the 1970s. This technique is also known as Radiant Thinking. A mind mapping actually has an idea or a central word, and there are 5 to 10 other ideas that come out of the central idea. Mind Mapping is very effective when used to bring up the hidden ideas that we have and make associations between them. Mind mapping is also useful for organizing information that is owned. The form of the diagram, which is like a tree diagram and branching makes it easy to reference one information to another.Mind mapping is a technique for preparing notes to help students use all the potential of the brain to be optimum. The trick, combining the work of the left and right brain. With the mind mapping method a student can improve memory up to $78 \%$. The difference between ordinary notes and mind maping is 1) in ordinary notes (a. Ordinary notes, b. Only in the form of writings, c. Only in one color, $d$. To review it takes a long time, e. Time needed for study longer, f. static); 2) in mind mapping (a. Mind map, b. In the form of writing, symbols, and pictures, c. Colorful, d. To review short it takes a short time, e. Time needed to learn faster and effectively, f. make individuals creative).Sugiarto (2004: 22) revealed that mind mapping is a noted technique that develops a visual learning style. Mind maps combine and develop the potential work of the brain contained in a person. With the involvement of the two hemispheres of the brain, it will be easier for someone to manage and remember all forms of information, both in writing and verbally. The existence of a combination of colors, symbols, shapes and so on makes it easier for the brain to absorb information received. Mind maps created by students can vary every day. This is due to the different emotions and feelings found in students every day. The pleasant atmosphere that students get when they are in the classroom when the learning process will affect the creation of mind maps. The task of the lecturer in learning is to create an atmosphere that can support student learning conditions, especially in the process of making mind mapping.

\section{Methodology Of The Research}

\subsection{Place and Time of Research Implementation}

The place where this teaching grand research was conducted in the lecture room of 210 ISIP UMSU Faculties in the second floor of building C class VII/ B/ Afternoon. While the 
implementation time of this research activity is one semester, aka six months, from July to December 2015 (seventh semester).

\subsection{Research subject}

The research subjects were VII IAIN students who numbered 29 on the first day and 30 students on the second day.

\subsection{Technique OF Analysis Data}

The data analysis technique is to use:

1. Observation of pre-research learning, which feels so heavy in teaching problems, formulating problems and explaining problems to others in seminar courses in the State Administration Study Program of FISIP UMSU.

2. Effectiveness of the introduction and understanding of mind mapping methods for all students of public policy seminar courses.

3. Filling the test by students before and after the research is conducted.

4. Fill out the observation sheet of the learning process during the research by collaborators and researchers themselves.

5. Through tests (pretest and posttest) research material before and after the action

6. Integrating data with the results of observations made during the walking cycle.

7. Pay attention to the research proposal, especially in determining the problem, formulating the problem, and explaining the problem when the seminar was conducted by one of the members of the group who got the best score in the inter-group discussion during cycle 1 and cycle 2 .

8. Providing interviews related to the ease or difficulty of a technique made in finding research problems

\section{Results And Discussion}

\subsection{Result}

In the initial phase of the activity called preliminary observation (before action is taken) as stated in the theoretical framework, learning conducted for public policy seminar courses requires students to prepare a research proposal seminar centered on the student's ability to present his research proposal and maintain the proposal when corrected and tested for quality by other students and lecturers in the course concerned.The basic problem that always recurs is when explaining the problem of research in the background, a student seems unable to master the problem correctly and seems not ready when getting questions about the problem. This condition occurs because the student does not master well the existing problems ranging from the source of the problem to the chronological problem in a systematic analysis.Actually the initial research conducted at the time of making the research background determines whether the problem can be mastered or not by the researcher. When basic research is carried out correctly, it will look chronological of the problem to the completion of what will be needed by the community regarding the problem.Even if this is understood correctly, when not formulating it in a research 
background, not all students are able to do it right. In addition, not all students can write it well on the power point of the research background at the time the seminar proposal was conducted.

Most students only copy all the words in the thesis proposal into power point. This makes the core point of the problem not focus and confuse the listener. When he will present it in front of the class at the time of the proposal seminar, students are confused in explaining the problem and why he is interested in researching his research proposal.There must be a new learning method applied to overcome this problem. This learning method must be able to make a comprehensive and simple mastery of the problem in its presentation and can help students when explaining the background of their thesis research proposal at this public policy seminar course.

Mind mapping learning method is one of the best alternatives to help solve learning problems as described above. This is because the mind mapping learning method can help students in looking at a problem more comprehensively and comprehensively and can help students in explaining research problems at the time of presentation.Realizing this, researchers are interested in applying mind mapping learning methods in mastering research problems and to facilitate students in explaining them at the time of the seminar.This study consists of two learning cycles, a description of the research in each cycle, the results and the discussion will be described as follows: Description of the research in each cycle consists of the planning stage, action stage, observation stage and reflection stage. The following will explain the course of the research process:

\subsubsection{Description of Research Cycle 1 a. Description}

The initial action in the first cycle is to realize that implementing mind mapping is not an easy thing for students. The simplest material needed to be trained for students regarding the problems they face, such as: mastering the problem and presenting the background of the problem in the proposal.Students are first trained in the mind mapping theory, after which they are asked to apply it to the practice of their thesis research proposal seminar one by one.

Table 1. Student Ability in Learning

\begin{tabular}{|c|c|c|c|}
\hline \multirow{2}{*}{ No } & \multirow{2}{*}{ LEARNING INDICATORS WITH MIND MAPPING } & \multicolumn{2}{|c|}{ QUALITY } \\
\cline { 2 - 3 } & Understanding the Theory of Mind Mapping & Total & $\%$ \\
\hline 1 & Ability to Use Mind Mapping & 10 & 33 \\
\hline 2 & Ability to Know Problems & 12 & 40 \\
\hline 3 & Problem Drawing Skills into Mind Mapping & 12 & 43 \\
\hline 4 & Ability to Move Mind Mapping Charts into Power Points & 11 & 37 \\
\hline 5 & Background Proposal & 11 & 37 \\
\hline 6 & Ability to Summarize Problems in Mind Mapping on the power point of the & 9 & 30 \\
\hline 7 & Ability to Explain Research Problems with Mind Mapping Help & & \\
\hline
\end{tabular}

Table 2. Evaluation of Learning Outcomes

(Evaluation of Achievement of Student Learning Outcomes from 30 Students) 


\begin{tabular}{|c|c|c|}
\hline \multirow{2}{*}{ No } & ACTIVITY INDICATORS & CYCLE 1 \\
\cline { 2 - 3 } & Understanding the Theory of Mind Mapping & TOTAL \\
\hline 1 & Ability to Use Mind Mapping & 10 \\
\hline 2 & Ability to Know Problems & 13 \\
\hline 3 & Problem Drawing Skills into Mind Mapping & 12 \\
\hline 4 & Ability to Move Mind Mapping Charts into Power Points & 11 \\
\hline 5 & Ability to Summarize Problems in Mind Mapping on the power point of the \\
\hline 6 & Background Proposal & 11 \\
\hline 7 & Ability to Explain Research Problems with Mind Mapping Help & 9 \\
\hline
\end{tabular}

Data on mastering problems in the research location and the ability to map problems on power points in the form of mind mapping and the ability to explain problems during the research seminar showed that the learning achievement scores were very low or all achievements were below $50 \%$ of the 30 students present. Means that there must be a repeat of the above indicator stages for the next cycle by changing the seriousness of the work through the problem of each student's proposal.

\section{b. Reflection}

The mind mapping theory has been taught and trained in learning groups through teamwork activities before the seminar is conducted and the presentation of work results in the team at the time the seminar is conducted. Then personally each student is asked to apply and make mind mapping personally according to the title that is assisted by a friend and the head of the group where the student is placed. However, when we noticed the mastery of material, mind mapping was still lacking (need repetition and deepening). Besides that, this condition was also exacerbated by the mastery of administrative theory teaching material that looked very weak when looking at the mistakes in making titles and taking research problems from the variables raised. After being asked the cause was because it was still focused on the title that was submitted to the head of the study program and not yet in the title of the respective title. Then the time to explain the problem when the presentation was held in front of the class during the presentation of the results of the group work, there was a lack of perfection in making power points, form diagrams, and the ability to explain the problems that had been visualized.In accordance with the results of the value analysis and learning activities to identify research problems, make them into mind mapping, create a background power point that uses mind mapping, and explain the research problems in the power point of the background of the problem through the mind mapping method offered, it is necessary learning is done in cycle two. The second cycle is done by repeating the mind mapping theory in accordance with the student's request again. After that, the group discussion carried out changes to the subject matter in strengthening the research proposal for those already accredited by the head of the study program only, and finally the proposal which had not been accredited by the study program head.This means that group work in cycle two becomes focused on completing proposals (background of problems) and making 
power points that have been filled with mind mapping. After that each group will be drawn by one person as a group representative to explain the results of mind mapping work.

Table 3. Student Activity in Learning (Activities in learning)

\begin{tabular}{|c|c|c|c|}
\hline \multirow{2}{*}{ NO } & ACTIVITY INDICATORS & \multicolumn{2}{|c|}{ QUALITY } \\
\cline { 3 - 4 } & & TOTAL & $\%$ \\
\hline 1 & Understanding the Theory of Mind Mapping & 28 & 97 \\
\hline 2 & Ability to Use Mind Mapping & 26 & 90 \\
\hline 3 & Ability to Know Problems & 23 & 79 \\
\hline 4 & Problem Drawing Skills into Mind Mapping & 28 & 97 \\
\hline 5 & Ability to Move Mind Mapping Charts into Power Points & 27 & 93 \\
\hline 6 & Ability to Summarize Problems in Mind Mapping on the power point of the \\
& Background Proposal & 28 & 97 \\
\hline 7 & Ability to Explain Research Problems with Mind Mapping Help & 29 & 100 \\
\hline
\end{tabular}

Table 4. Learning Evaluation (Evaluation of student learning outcomes)

\begin{tabular}{|c|c|c|c|}
\hline \multirow{2}{*}{ No } & ACTIVITY INDICATORS & \multicolumn{2}{c|}{ CYCLE 2 } \\
\cline { 2 - 4 } & & TOTAL & $\%$ \\
\hline 1 & Understanding the Theory of Mind Mapping & 28 & 97 \\
\hline 2 & Ability to Use Mind Mapping & 26 & 90 \\
\hline 3 & Ability to Know Problems & 23 & 79 \\
\hline 4 & Problem Drawing Skills into Mind Mapping & 28 & 97 \\
\hline 5 & Ability to Move Mind Mapping Charts into Power Points & 27 & 93 \\
\hline 6 & Ability to Summarize Problems in Mind Mapping on the power point of the & 28 & 97 \\
\hline 7 & Background Proposal & 29 & 100 \\
\hline
\end{tabular}

The study evaluation data table above shows an increase in the number of students who have mastery of mind mapping concepts and theories and their presentation in cycle 2 , this can be seen from the learning evaluation data compared to cycle 1 and cycle 2 . From the table above it can be seen that all indicators have significant improvement. The number of participants in cycle one was 30 while in the second cycle there were only 29 people. However, the table above shows that the learning achievement and mastery of the indicators raised are very high.Through observations and brief interviews, it turned out that they were aware of the mind mapping theory and its application made the cycle one very low. After going through a more intensive and 
repetitive theory and training repetition and can see the mistakes of other friends seen. All indicators experience significant strengthening.

\subsection{Discussion}

From the results of the cycle one test, it can be seen that understanding and mastery of the theories and concepts offered are still very far and less than expected. If we look at the process again, it seems that student activity has not been maximized since the teaching of mind mapping theory to the use of mind mapping in the seminar.

In this second cycle, there is an increase in the posttest results in cycle one and cycle two. As shown in the following tables and graphs:

Tabel 5. Learning Evaluation

\begin{tabular}{|c|c|c|c|c|c|c|}
\hline \multirow{2}{*}{ No } & \multirow{2}{*}{ ACTIVITY INDICATORS } & \multicolumn{2}{|c|}{ CYCLE 1} & \multicolumn{2}{|c|}{ CYCLE 2} & \multirow{2}{*}{$\begin{array}{l}\text { GROWTH } \\
\text { NUMBERS }\end{array}$} \\
\hline & & TOTAL & $\%$ & TOTAL & $\%$ & \\
\hline 1 & Understanding the Theory of Mind Mapping & 10 & 33 & 28 & 97 & 7.2 \\
\hline 2 & Ability to Use Mind Mapping & 12 & 40 & 26 & 90 & 9.8 \\
\hline 3 & Ability to Know Problems & 13 & 43 & 23 & 79 & 11.2 \\
\hline 4 & Problem Drawing Skills into Mind Mapping & 12 & 40 & 28 & 97 & 9.7 \\
\hline 5 & $\begin{array}{c}\text { Ability to Move Mind Mapping Charts into } \\
\text { Power Points }\end{array}$ & 11 & 37 & 27 & 93 & 8.5 \\
\hline 6 & $\begin{array}{l}\text { Ability to Summarize Problems in Mind } \\
\text { Mapping on the power point of the } \\
\text { Background Proposal }\end{array}$ & 11 & 37 & 28 & 97 & 8.5 \\
\hline 7 & $\begin{array}{l}\text { Ability to Explain Research Problems with } \\
\text { Mind Mapping Help }\end{array}$ & 9 & 30 & 29 & 100 & 5.8 \\
\hline
\end{tabular}

The graph and table above say that the number of students who master the understanding or ability of each indicator item increases.The fact above proves that learning by using mind mapping method in public policy seminar courses by students turns out to provide convenience in formulating problems and explaining problems at the time of the seminar. The results of this learning method are very satisfying at the end of their application.

\section{Conclusion}

Based on the results of classroom action research in the VC Morning Study Program of IAN FISIP UMSU, it can be concluded that the role of mind mapping in public policy seminar courses can help improve the ability of students to master research problems and formulate research problems well and are expected to be able to facilitate students in explaining research problems when conducting seminar activities in front of the class. Because this course applies the learning process that is direct practice in the classroom and is related to student learning achievements in their final exams. The role of the lecturer in this study can be a material of selfintrospection in delivering learning material. Using mind mapping can help the lecturer in 
developing the ability to master research problems, writing research problems and submitting research problems. So by using this mind mapping in mastering the research problem, students and lecturers are helped in the Public Policy Seminar subject.The form of learning planning involving mind mapping is in accordance with the plan that has been carried out through two cycles, namely in the cycle of one student being taught mind mapping theory, then grouping three groups. Students are put together in groups with 6 to 7 students in one group during the discussion. Students who are in groups, choose one member who is ready to make a mind mapping of the title of the research proposal and be helped together until it is complete. When finished, it is asked to present the mind mapping in the form of power points in front of the class.

In the cycle two students were given reinforcement related to mind mapping theory, then grouped into 3 groups. However, this time the group was obliged to all students prepare their respective proposals and help each other in group activities to make power points that contained their mind mapping. All of that must be delivered in the form of research seminars when the second cycle is carried out. After evaluating it turns out that student competencies increase from cycle one to cycle two. When viewed from the results of the evaluation of student learning, the characteristics of learning outcomes show that mind mapping involvement shows a change in learning conducted by students. From the difficulty of finding a problem to the ease of finding a problem because of using mind mapping, besides explaining it feels easier and simpler.The faculties possessed by students in the learning process when applied to mind mapping are increasing their ease in finding research problems and the easier they explain the research problem and make them easy when they encounter questions related to the research problems they raise in their thesis proposal. Finally, the ability and value of students achieve an increase in learning completeness. From the evaluation results, the researcher has a description that providing learning is attempted to involve mind mapping to facilitate students in finding problems, formulating problems and explaining problems in public policy seminar courses.

\section{References}

Arikunto, Suharsimi. (2002). Metodologi Penelitan. Jakarta: PT. Rineka Cipta.

Buzan, Tony. (2008). Buku Pintar Mind Map. Jakarta : PT. Gramedia Pustaka Utama.

Djamarah, Syaiful Bahri dan Aswan Zain. (1997). Strategi Belajar Mengajar. Jakarta: Rineka Zipta.

Djaafar, Tengku Zahara. (2001). Kontribusi Strategi Pembelajaran Terhadap Hasil Belajar. Jakarta : Universitas Negeri Padang.

Gafur, Abdul. 1989. Desain Intruksonal Suatu langkah Sistematis Penyusunan Pola Dasar Kegiatan Belajar Mengajar. Solo: Tiga Serangkai.

Uno, Hamzah B. (2007). Teori Motivasi dan Pengukurannya. Jakarta: Bumi Aksara.

Syah, Muhibbin.(1995). Psikologi Pendidikan Suatu Pendekatan Baru. Bandung: Remaja Rosdakarya.

Purwoto. (1997). Strategi Belajar Mengajar. Surakarta: Sebelas Maret University Press

Sugandi, Achmad. (2004). Teori Pembelajaran.Semarang: IKIP Semarang Press.

Sugihartono dkk. (2007). Psikologi Pendidikan. Yogyakarta : Universitas Negeri Yogyakarta. 
Budapest International Research and Critics Institute-Journal (BIRCl-Journal)

Volume I, No 3, October 2018, Page: 23-34

e-ISSN: 2615-3076(Online), p-ISSN: 2615-1715(Print)

www.birci-journal.com

emails; birci.journal@gmail.com

birci.journal.org@gmail.com

Sanjaya, Wina. (2006). Strategi Pembelajaran berorientasi Standar Proses Pendidikan.Jakarta: Prenada Media Group.

Sudjana, Nana. (2000). Dasar-Dasar Proses Belajar Mengajar. Bandung: PT. Sinar Baru Algensindo.

Sugiarto. Iwan. (2004). Mengoptimalkan Daya Kerja Otak Dengan Berfikir.Bandung: Kaifa. Thaha, Chabib. Dkk. (2004). Metodologi Pengajaran Agama. Yogyakarta: Pustaka Pelajar.

Wena, Made. (2011). Strategi Pembelajaran Inovatif Kontemporer Suatu Tinjauan Konseptual Operasional. Jakarta : Bumi Aksara 